\title{
Imaging the Past: \\ Cartography and Multicultural Realities of Croatian Borderlands
}

\author{
Borna Fuerst-Bjeliš
}

Additional information is available at the end of the chapter

http://dx.doi.org/10.5772/46223

\section{Introduction}

Maps have long been central to geographical inquiry. The most usual approach to maps and cartography until recently dealt with its role in presenting a factual statement about geographical reality within the frames of actual survey techniques and skills of a cartographer. Recent researches since the end of $20^{\text {th }}$ century tend to subvert the traditional, positivist model in analyzing the maps, replacing it with one that is grounded in iconological and semiotic theory of the nature of maps. According to J.B. Harley, one can understand a map as a social construction of the world expressed through a medium of cartography, or as a socially constructed image of reality.

Maps always represent much more than merely physical nature and inventory of space. Maps understood and considered as social construction of reality have a number of layers, including the symbolic one. They are conveyors of meanings, messages and perceptions of the world - and not only of an individual cartographer, but also of common societal and cultural values. They reveal what may be called the spirit of time: philosophical, political, religious and general socio-cultural context.

As images, maps should be put and studied in the appropriate context, i.e. period and place. Moreover, maps as images are never neutral or value-free; they are all social, political and cultural. Understood as images, maps can be used on one hand as a tool of disseminating messages, and, on the other hand as a source in analyzing the perceptions of past places, territories and societies.

Researching past images through maps is of particular interest in multicultural spaces, where a variety of different cultures, religious systems, complex ethnic structures and 
imperial systems have met. Borderlands are typical spaces where a multiplicity of such contacts reflect and produce a multiplicity of perceptions and images.

Early modern period in Croatian history is burdened with frequent changes of borders between three imperial systems with different religious systems and cultural traditions that have intertwined on the Croatian territory, and consequently reflect different attitudes toward borderlands. Accordingly, a map could and often did represent an image with multiple layers of meaning and perceptions. What one can put into relation here is Habsburg and Venetian cartography. Through a number of examples of the Croatian borderlands, the main aim is to reveal the symbolic layer of the map that leads us into the process of imaging the past, i.e. opening the abundance of different perceptions in the multicultural realities of the Croatian borderlands.

Through an analysis of the symbolic layer through graphic elements, place-names and other inscriptions, maps of Croatian borderlands have revealed two distinct levels of meaning. The first one is related to the specific relation of the state authorities to the border region, their particular interests and understanding of its importance. Maps have been used as a tool for disseminating the political message of power and control primarily through methods and techniques of emphasizing (over-exaggerating) or ignoring and omitting. At this particular level of meaning, we are dealing with directly opposing images of the borderlands realities, depending on the political sides and their official cartographies.

At the second level of the meaning maps have revealed the most common socio-cultural images of the borderlands that are, unlike cartographic expressions of different state power interests, expressed equally in all European cartographic traditions. These images include: environmental perceptions of the borderlands as depopulated and devastated area; distinction of social groups, related systems of beliefs, territorialization and deterritorialization of borderland communities; perception and formation of regional identities; and comprehension of the temporality of the border and the continuity of Croatian territory.

\section{Theoretical and methodological frame}

\subsection{Image-reality dualism}

The approach to imaging the past through a medium of cartography links two key concepts, such as image and map. Imagery is a subject of enquiry in fields as diverse as cognitive science, literature (imagology), human geography or cartography. These concepts, on different sides in the image-reality dualistic model in most modern writings, are being rethought and are actually converging only in recent postmodern works. Image-reality dualism opposed subjective and objective spaces, unreal and real geographies, mental images and cartographic representations. Reality was thus related to objective geographic fact, represented by a map, while images were considered as "false understanding", or a "coherent, logical, rule-governed system of errors" [1, 2]. Phillips [2] is questioning imagereality dualism arguing that the "general characterization of images as unreality is contradicted by a tendency to privilege certain types of images as reality". Maps as 
geographic representations have been commonly accepted as realistic, although constructed according to the conventions of artificial perspective [3]. Geographic faith in maps has been made possible largely by the development of techniques of scientific cartography and the maps "conquered the world of representation under the banner of reason, science and objectivity" [1]. However, geographic "reality" is not a nonimage, as argued by Phillips [2]. "Reality" is humanly constructed and merely conventional, and the "truth" is constructed, theoretically and politically committed. At this point we start to question the "unquestionable scientific objectivity" of the cartographic representation of the world and to question the map as a "mirror of reality". Recent researches witness these developments as "epistemic break between a model of cartography as a communication system, and one in which it is seen in a field of power relations, between maps as presentation of stable, known information and mapping... in which knowledge is constructed" [4,5].

On the other hand, since the 70s, the subjectivity and "naïvete" of images have been questioned by iconographers and iconologists as well [2]. They have shown that images can be read as explicitly social and political texts and not just as mental representations. Iconography defines images as a sign system and locates them at the social level [6].

\subsection{Deconstruction as a methodological strategy}

Eventually the two concepts begun to merge particularly in Harley's understanding of maps as socially constructed images. Although some scholars anticipated main ideas earlier, for instance in well known Korzybski's statement that "the map is not the territory it represents" [4] or that "every map is... a reflection partly of objective realities and partly of subjective elements" [7]. Harley formulated a broad strategy for understanding how maps redescribe the world, like any other document, in terms of relations of power and of cultural practices, preferences and priorities [8]. "...Maps are at least as much an image of the social order as they are measurements of a phenomenal world of objects" [9]. He derived basic ideas from writings of Michel Foucault about the "omnipresence of power in all knowledge even it is invisible or implied", including the particular knowledge encoded in maps, as well as Jacques Derrida's work on the rhetoricity of all texts. The concept of "text" does not imply the presence of linguistic elements, but the act of construction, so that maps, as "construction employing a conventional sign system become texts. By accepting the textuality of maps we are able to embrace a number of different interpretative possibilities [9].

In his seminal work on deconstructing the map Harley [9] argues that deconstruction as discourse analysis, demands a closer and deeper reading of the cartographic text and may be regarded as a search for alternative meaning. It means reading between the lines of the map - "in the margins of the text" and a search for metaphor and rhetoric in the textuality of the map [9]. Deconstruction is, as Harley sees it, a broad strategy, more than a precise method or set of techniques.

However, there are some important presumptions, or contexts in the research agenda of map deconstruction. Harley articulated the importance of context around three issues [8]. The first one is the context of the cartographer, including the appreciation of personal views, 
attitudes and skills, including the local knowledge that is related to the internal power of map. This context is related to the general statement that maps are, like art, a particular human way of looking at the world. Second context is a context of other maps that ensure and emphasize the importance of multiple maps, perspectives and polysemy. Third context is the context of society and points out to the importance of positioning the map within societal-power relations, i.e. within specific historical, social and political conditions, from which it cannot be extracted or generalized $[2,10]$. The contexts of other maps and society (or societal environment) are directly connected and linked to the external power of the map. It can be seen through maps made by different actors that are reflecting different or even opposed approaches to the territory that were embedded in the society and culture of the particular period and place [11].

Based on the iconographic studies by E. Panofsky [6], Harley has defined a number of semantic layers of the map. The symbolic one often has ideological connotations. It refers to power relationships, distinction of social groups and system of beliefs, to worldviews and to what may be called as a spirit of time.

Scholars in Croatia have recently addressed these topics from various perspectives. The first writings embrace the topics of cartographic perceptions and the state power interests of the multiple borderlands of Croatia [11,12], different perceptions of Croatian lands in Croatian and other European cartographic traditions [13], toponymy and perceptions [14,15], the relation of cartography, place-names and regional identities [16], the political rhetoric of maps [17] and recently the cartographic visualization and the image of Other [18].

Imaging the past of the multicultural space of the early modern Croatian borderlands was based primarily on deconstructing the maps of the time, as the main research and methodological approach. Reading between the lines, in the margins of the textuality of map, searching for metaphors, evaluating the presence or absence (silencing) of information; in short - tracing the rhetoric of map and its symbolic meaning and/or political messages. Key elements of analysis were place-names and smaller cartographic transcriptions and objections as they are as much related to an invisible social world and to ideology as they are to the material world that can be seen and measured. All the contexts were appreciated, especially the importance of the multiplicity of perspectives.

The analysis is based on the cartographic originals of the time from the map collections of the Croatian State Archives, The National and University Library and the Museum of Croatian History, as well as on the numerous published facsimiles [19, 20, 21]. A selection of maps and a comparative approach enable an insight into the different cartographic representations and images of the borderlands within different traditions and even within the framework of a single, overarching tradition.

\section{Spatial, temporal and cultural context}

In the course of three centuries $\left(16^{\text {th }}-19^{\text {th }}\right)$, the territory of Early Modern Croatia was determined by the borderlands of three imperial systems of the time: Habsburg Monarchy, 
Ottoman Empire and Venetian Republic (Figure1). Borders were, consequently, significantly influential in political, social, cultural, and demographic sense.

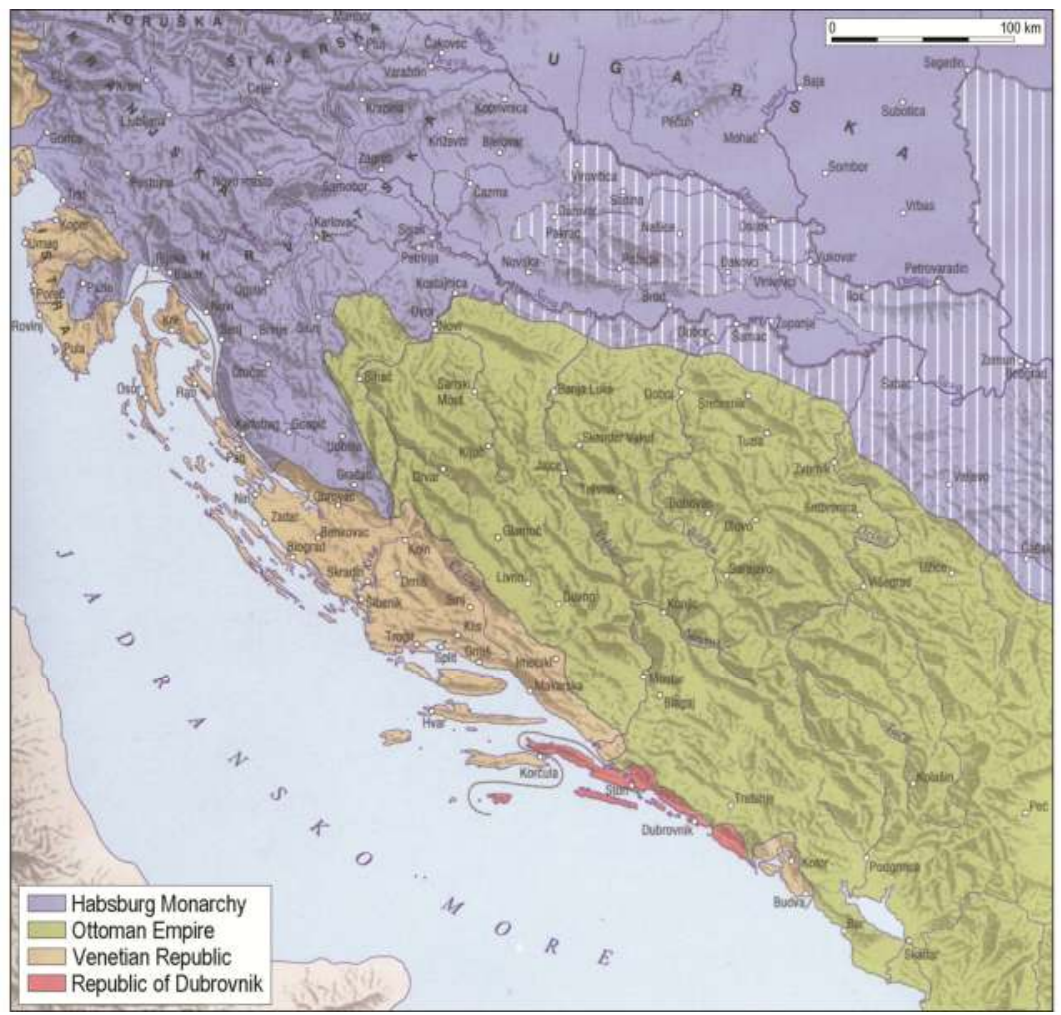

Figure 1. Croatia and triple border, $18^{\text {th }}$ century, [22]

In the history of mapping the Croatian territory, the Early Modern Period was directly connected with military operations i.e. the process of Ottoman retreat. This is the period when cartography developed into so-called "military cartography", practiced in military institutions. Thus, military engineers were mainly the creators of new maps. However, the cartographers were rarely independent decision makers, free of financial, military or political constraints. The context of the cartographer, as Harley has pointed out [8], also included personal skills and the cartographer as a person living in a particular society and in particular political circumstances. Accordingly, map could and often did represent an image with multiple layers of meanings and perceptions and, but also, emphasized features of strategic importance of the state or empire, i.e. exercising the external and internal power of cartography [9].

Triple border conditioned a true multicultural surrounding. Croatian territory was a "meeting point" of Western and Eastern world, Christianity and Islam as well as maritime and continental traditions. Frequent changes of borderlines were followed by population 
shifts and migration, introduction of new (other) social and cultural groups, as well as leading to mixed cultural, religious, ethnic groups and lifestyles in borderlands. Appreciation of these differences, sense of uniqueness and perception of otherness, through the territorialization, conditioned the creation of spatial images and eventually resulted in regional identity.

\section{Disseminating the political message of power and control}

Maps are part of a general discourse of power [5]. Throughout history, as much as other weapons, maps have been an intellectual weapon of imperialism and of territorial pretensions of empires and states. In this imperial context, maps regularly supported the direct execution of territorial power. The specific functions of maps in the exercise of power range from global empire building to the preservation of the nation state and to the assertion of local property rights. Maps with their hidden agendas and texts beyond the text, speak political language. As George Orwell said that the "political language is.... designed to make lies sound truthful..." (See [5]), scholars consider maps as politicized documents with the ethical concerns $[17,23]$.

In his most influential work on deconstructing the map, Harley [9] wrote about the power/knowledge matrix and stated that especially where maps are ordered by government it can be seen how they extend and reinforce the legal statutes, territorial imperatives and values stemming from the exercise of political power. He also distinguished external power when maps are linked to the centers of political power and when power is exerted on cartography and with cartography from internal power that is expressed through the political effects of maps in society drawn from the cartographic process (selection, generalization, abstraction).

Following the selection of Venetian and Habsburg maps as well as map by Croatian cartographer Vitezović, representing the borderlands is a very good example of these relations. Venetian cartographic policy was primarily subordinated to the Republic's political and administrative purposes. They have, generally, more information about political or administrative divisions and contain much less of geographical inventory. This is an example of direct dissemination of the political message of power and control over the territory. Many of the conventional tools in map making were used in doing this; such as deliberate or "unconscious" (but ideological) distortions and omissions (the "silence", see [9]) on the maps.

\subsection{Opposing images as messages}

The examples of Coronelli's map of Dalmatia of 1700 [19] and Alberghetti's map of Dalmatia of 1732 [20] enable us to distinguish two different stages for approaching the Venetian borderlands. Coronelli's map was still based mainly on the compilations, while Albeghetti's is already based on field survey. However, apart from technical differences these maps express the political message in the corresponding way. Coronelli, as the official Venetian 
cartographer, was the most prominent figure in promoting Venetian politics regarding the territorial pretensions on his maps. They were an important instrument for emphasizing the Venetian conquest over the Ottomans. Coronelli's map of Dalmatia is a general regional map on a rather small scale. The map charts Venetian Dalmatia, the territory of the Republic of Dubrovnik, parts of Croatia, Bosnia, Serbia and surrounding lands (Figure 2).

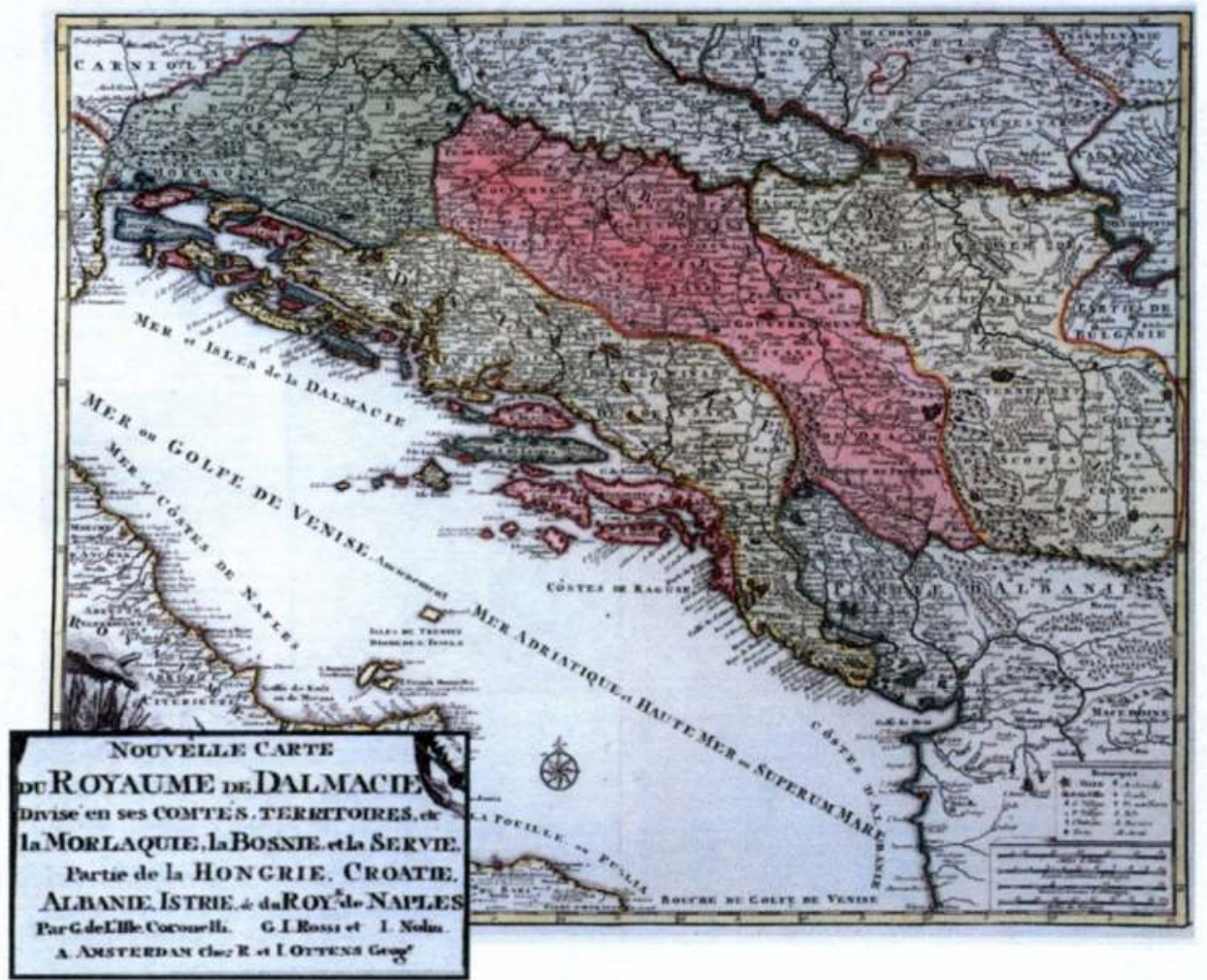

Figure 2. Coronelli's Map of the Kingdom of Dalmatia, La Morlaquie, Bosnia and Serbia ..., 1700, facsimile in [19]. Emphasized by the author.

The whole inland area between the river Sava and the Adriatic is compressed along its north-south axis. But, on the other hand, the territory of Venetian Dalmatia is unproportionally vast, especially the inland part. These "distortions" are a testimony to the expression of state power interests and an approach to the border area; emphasizing and over-exaggerating its possessions and importance, while ignoring the Ottoman side at the same time [11]. The rhetoric of the map is accompanied with the well known tool of expressing the Venetian possession of the Adriatic aquatorial space as "Mer ou Golfe de Venise" and in addition, introducing the "Mer et Isles de la Dalmatie", that as a hydronym does not really exist apart from the political context of exercising power and control over Venetian Dalmatia. 
The beginning of the $18^{\text {th }}$ century was a time of relatively numerous changes of the border in Dalmatia and a time of intensive cartographic work. Demarcation maps from that time represent the very first topographic presentation of the Dalmatian hinterland. Alberghetti's supplemented map of Dalmatia from 1732 presents three borderlines with the Ottoman Empire; the old one from 1671 (Linea Nani), the one from 1700 (Linea Grimani) and the newest one from 1720 and 1721 (Linea Mocenigo). The map contains the administrative division of the territory that most Venetian maps have. The topography is very detailed except orography and communication. Beyond the border, there is no presentation whatsoever, except for some very general textual notifications of what may be found: "Parte della Licca", "Parte della Bossina", "Ercegouina". Thus, the central element of the map is the development of the Venetian - Ottoman border in terms of territorial extension of Venetian republic, disseminating the message of the Republic's power and control over the territory. An obvious ignorance of Ottoman presence (and even existence) is shown through the omission of recording their territory across the border [11]. In such a context the omissions are as important as emphasizing (the "silence").

These examples of decorative (Coronelli) and "scientific" cartography (Alberghetti), in spite of differences in a technical sense, have some unifying and constant elements that characterize the Venetian cartography of the borderlands. That is a strong rhetoric of power and control in promotion and giving legitimacy to the territorial occupation.

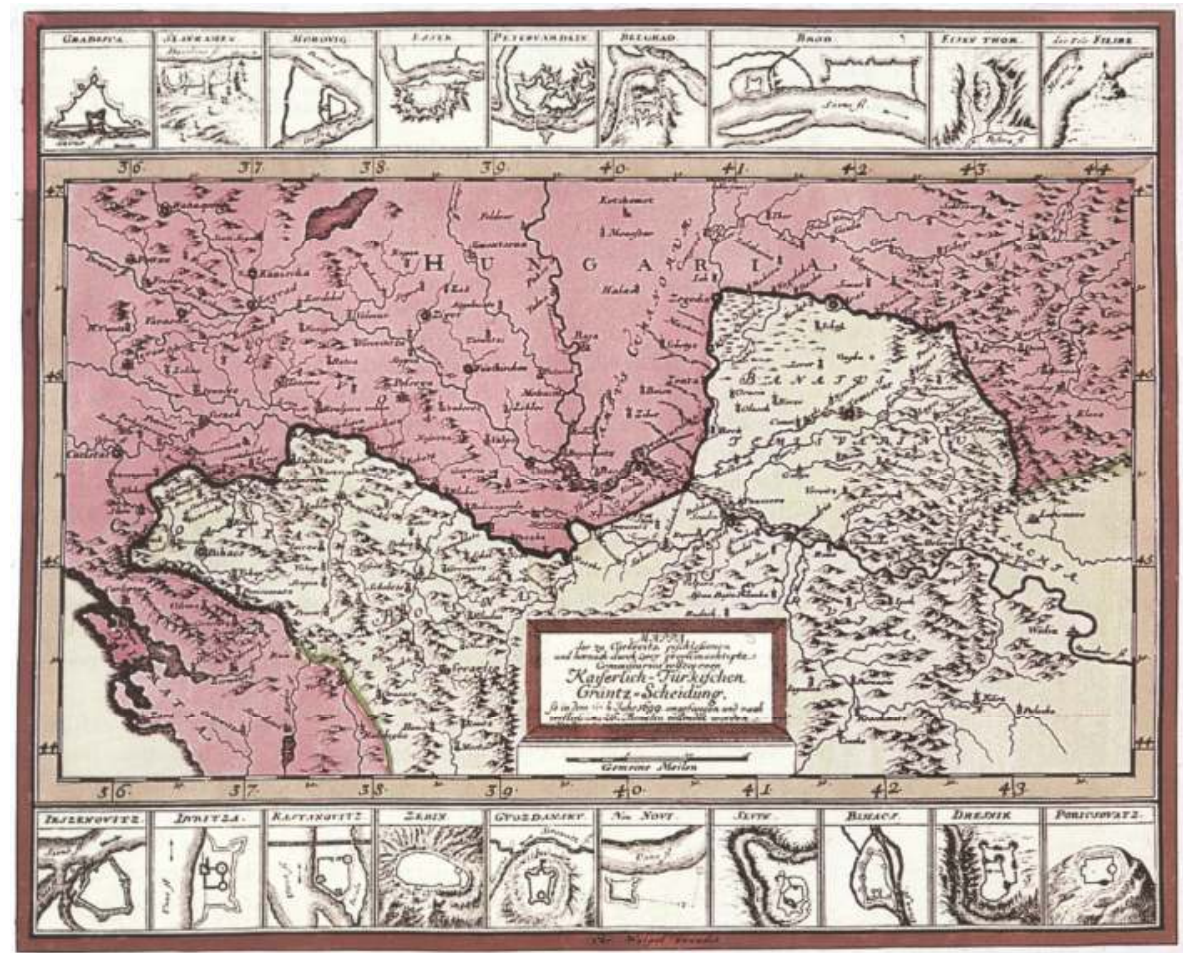

Figure 3. Weigl's Map of the Imperial - Turkish border, 1702; facsimile in [20] 
Habsburg cartography was guided completely by military and strategic interests and needs. Highly aware of the extreme importance of knowing the border area in the strategy of warfare, Habsburg cartographers had already surveyed and mapped the territory long before the $18^{\text {th }}$ century. The occasion of the peace treaty of 1699 and the need to fix the new border between the Habsburg Monarchy and the Ottoman Empire was the direct cause of the first topographical survey along the border.

The central interest in the new border is shown on Christoph Weigl's Map of the Imperial Turkish border after the peace treaty, presumably around 1702 (Figure 3) [20,24]. The main theme of the map is the border, which is the most expressive element on the entire map as well as the territory of Habsburg Monarchy, which is the only colored element. The color has always been a very strong tool. Different colors send different messages to the audience. Strong, cardinal colors like red color for instance, as employed on Weigl's map, were always the imperial colors etc. On the other side, we are discovering silencing: there is not much content outside the borderline, but again a rich inventory of military fortifications on the margins of the map, communicating the undisputable power, security and the organization of the Monarchy.

\subsection{Communicating the political program}

There is an example of more specific approach to the territory and borders of Croatia, exercising the internal power of map aiming to formulate a political program. Pavao Ritter Vitezović, Croatian cartographer and representative in the demarcation commission in the occasion of Peace Treaty of Srijemski Karlovci (1699) between Habsburg Monarchy and Ottoman Empire, dissatisfied with the newly established borders, tried to present to the Austrian court his view of the "real historical" borders and territory of Croatia [25].The Map of the whole Kingdom of Croatia (Figure 4) represents the entire kingdom of Croatia in its ancient, historical limits as confirmed by the king Ludovic in the $16^{\text {th }}$ century. Along with the 1699 demarcation, he drew in the former borders. The eastern border follows the line of the Vrbas river in contrast to the actual one on the river Una, lying more westerly and thus, compressing the Croatian territory. The map was followed by the document "Croatia Rediviva" (1700) [26] altogether aiming to produce and communicate the knowledge of considerably larger territory of "historical" Croatia. Vitezović's map is, among other contexts which will be discussed later, exercising the internal power of cartography in power/knowledge matrix and communicating political ideas and program to the targeted audience.

All these examples clearly show the external and internal power of map that is not necessarily separated. One particular map can express both - the external power which is imposed from above, especially when cartography became nationalized, but also the internal power, exercised by cartographers themselves, that is related to the context of cartographer. 


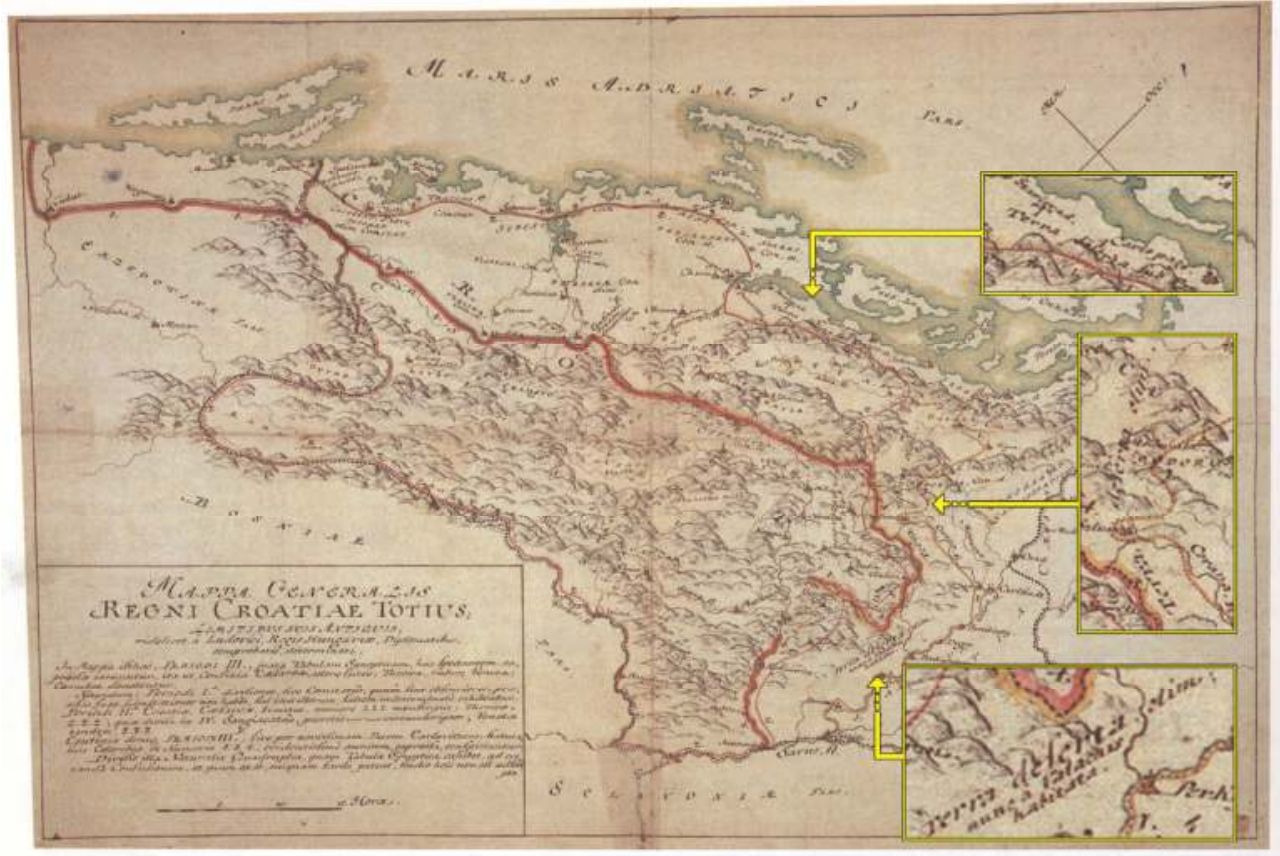

Figure 4. Vitezović's Map of the whole Kingdom of Croatia, 1699, facsimile in [19] "Terra deserta olim nunc a Valachis habitata" and "Terrae desertae" along the borderlands. Emphasized by the author.

Triple border and "meeting point" of different political systems on the territory of Croatia conditioned different imaging of the borderland through a medium of cartography. These images are politically informed and valued and often directly opposed, giving legitimacy, importance and power to one side and ignoring and silencing the other. Thus, these examples show that the rhetoric of map include also the concept of otherness.

\section{Socio-cultural images}

Opposed to images discussed above that reflect different attitudes of different imperial forces and that can be easily recognized through corresponding official cartographic traditions, there is another level of meaning that reveal common socio-cultural images to all European cartographies, regardless of political affiliation. These images reflect social recognition and territorialization through the distinction of social otherness and, on the other hand, perceptions of territorial continuity in the circumstances of border fluctuation, through the distinction of territorial otherness. There is a number of related concepts that are embedded in maps and leading eventually to the creation of regional concept and identity. That is appreciation of differences, uniqueness and otherness that, through the territorialization, result in specific spatial images and regional identity $[11,16]$. 


\subsection{Morlacchia: otherness, territorialization and regional concept}

The first image of the triple border area is related to the recognition of Morlacchi, a distinct social group as Other. Their presence in the borderlands is a consequence of the population shifts due to the warfare and border fluctuations. Autochthonous sedentary population abandoned land and migrated towards more secure areas, while a large portion of the Croatian borderlands became a destination of new semi-nomadic pastoral communities from the Dinaric mountain hinterland. These borderlands communities are generally called Vlachs or Morlacchi in the Venetian tradition. Morlacchi communities partly immigrated to the borderlands area spontaneously, combining the pastoral economy with military service, while they were partly colonized and settled by the official politics of Venice and Habsburgs.

The toponyms Morlaccha or Morlacchia with a number of some other corresponding forms, such as Morlacca, Morlacha, Murlacha and Morlakia can be found on the maps as early as the $16^{\text {th }}$ century (Figure 5).

Originating from the Venetian term for social community, the derived toponymic forms became a common name for the border region for more than three hundred years in circumstances where three imperial forces met. Throughout the course of centuries, the term Morlacchi has been related to the territory they have settled. The term gradually has got the spatial connotation $[14,16]$.

Territorialization is seen as a reflection of perceived otherness of Morlacchi community; primarily through different social organization, lifestyle and customs in relation to the prevailing population. Perception of otherness and uniqueness is the basis of regionality and regional identity that is leading to the construction of the regional concept of Morlacchia. The image of otherness is very well expressed on Vitezović's map (Figure 4). What we can read "between the lines" of the notification along the border: "Terra deserta olim nunc a Valachis habitata" (deserted, depopulated and uninhabited land, yet inhabited by Vlachs!) is that Vlachs are considered as Others in terms of social and religious differentiation $[11,16]$.

It has been clearly proved [14] that the regional concept of Morlacchia is found to be common to all European cartographies, even if the term for the social group is Vlach (Habsburg tradition). Morlacchia was an important regional concept if looking at the significance given by the typography (see Figure 2, 5). On Coronelli's map for instance, La Morlaquie is listed in the title of the map along with Bosnia, Serbia, Hungary and Croatia.

With the disappearance of triple border conditions by the end of the wars with Ottoman Empire and the fall of Venetian Republic in $19^{\text {th }}$ century, the context of significance within which the Morlacchi community have been evaluated throughout the centuries, was dissolved. 


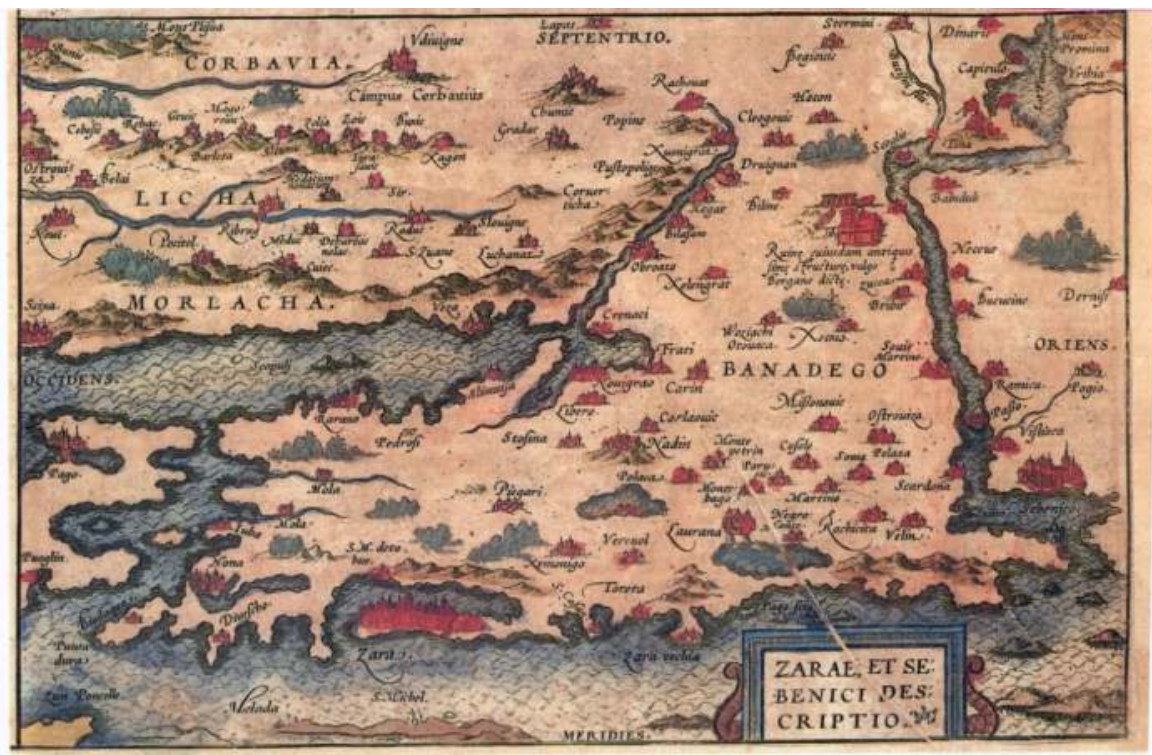

Figure 5. Bonifačić's Map of the surroundings of Zadar and Šibenik with the region of Morlacha, 1573, facsimile in [19]

This change is clearly recognizable in the disappearance of toponyms associated with Morlacchi. Constructed in the multicultural border circumstances of the $16^{\text {th }}-19^{\text {th }}$ centuries, they disappear from the maps with the change of circumstances that created them. Following the change in the rhetoric of the maps, we can read about the territorialization as well as about the de-territorialization of borderland communities.

\subsection{Environmental image of the borderlands}

Coming back to the aforesaid statement "Terra deserta olim nunc a Valachis habitata" by Vitezović we are about to open a new question of environmental image of the borderlands. Now, the other part of the statement shall be emphasized: "Terra deserta". Vitezović has repeatedly put the notification along the border, constructing the image of Croatian borderlands as deserted and devastated (see Figure 4). Apart from Vitezović's terrae desertae, one can find other examples of environmental rhetoric imaging the devastated borderlands on Coronelli's map of Istria and northern Dalmatia (1688) [21] through the records of destroyed and abandoned cities and fortresses: "Starigrad Citta distructa" or "Carlobago distructa" etc. Environmental image of borderlands as deserted, devastated area appears as common to all regardless their imperial or cartographic background.

\subsection{Turkish Croatia: Territorial continuity, otherness and regional concept}

The issue of old and new border, already discussed earlier in the context of communicating the political message, will be considered again, but in other contexts of a socio-cultural image, distinction of territorial otherness and regional identity. 
Although Croatia regained a large parts of its territories by the peace treaty of Srijemski Karlovci (1699), it failed to get back some of its historical lands. That was, primarily, the area between the Una and Vrbas rivers - the area between the new and the old border. A number of cartographers, along with the new border drew in the old one as well. Some of the examples are already discussed Vitezović's Map of the whole Kingdom of Croatia (1699) (see Figure 4) and Müller's Map of Hungary (1709) [19]. There are cases where the inscription, either a general one like "Croatia", or a more specific one like "Turkish Croatia" cover the interfluves territory that is beyond the new actual border, but integral part of the historical Croatian territory. On Weigl's Map (see Figure 3) for instance, the inscription "Croatia", regardless of the actual borderline, is written more easterly across the river Una, over the Ottoman territory. Coronelli (1732) [19], although of different imperial and cartographic affiliation, used the color, the line and the text to differ the interfluves from the rest of Bosnia (Ottoman territory) as well as from the rest of Croatia, lying under the inscription of "Croacie". The example of Schimek's map of 1788 (Figure 6), representing Viennese cartography, also shows the clear distinction of "Turkisch Croatien".

There is quite a number of maps of different political backgrounds and cartographic traditions that are equally sharing the same image of Turkish Croatia, i.e. J. von Reilly's map (1790), map edited by Artaria and Comp. (1807), J. Szeman's map (1826), E. Zuchery's map (1848), Halavanja's map $(1851)$ [19, 20].

"Reading between the lines" and searching for metaphors will lead us to the perception of temporality of border fluctuation in these centuries of their frequent changes. Consequently, the territory of Turkish Croatia reveals an image of the interfluves as integral Croatian territory in spite of the newly established border. This is an image of the new borderline as a temporary condition in relation to the "real historical" border. The image include the awareness of a temporality of the borders and understanding and appreciation of the continuity of Croatian territoriality (Turkish CROATIA; emphasized by the author). At the other hand, the image reveal the distinction of territorial otherness (TURKISH Croatia, emphasized by the author) that is grounded in the distinction of "Turkish"/Muslim as Other and the distinction of Christian Croatia versus Muslim Croatia. Thus, the image is pointing out to the awareness of different religious identities of the twofold region.

The example of Turkish Croatia opens two levels of reading: old and new border as real historical border versus temporary border; distinction of different religious and cultural identities, Christian versus Muslim Croatia. The consciousness of the otherness and uniqueness as related to the territoriality is leading to the creation of regional identity. These elements are formative elements of regional identity and the regional concept in both examples: in Morlacchia as well as in Turkish Croatia [11,16].

\subsection{Reflections}

Still, the development and reflection of these regional concepts are different. Turkish Croatia has undergone the process of conceptual translation. By the mid $19^{\text {th }}$ century it has changed 


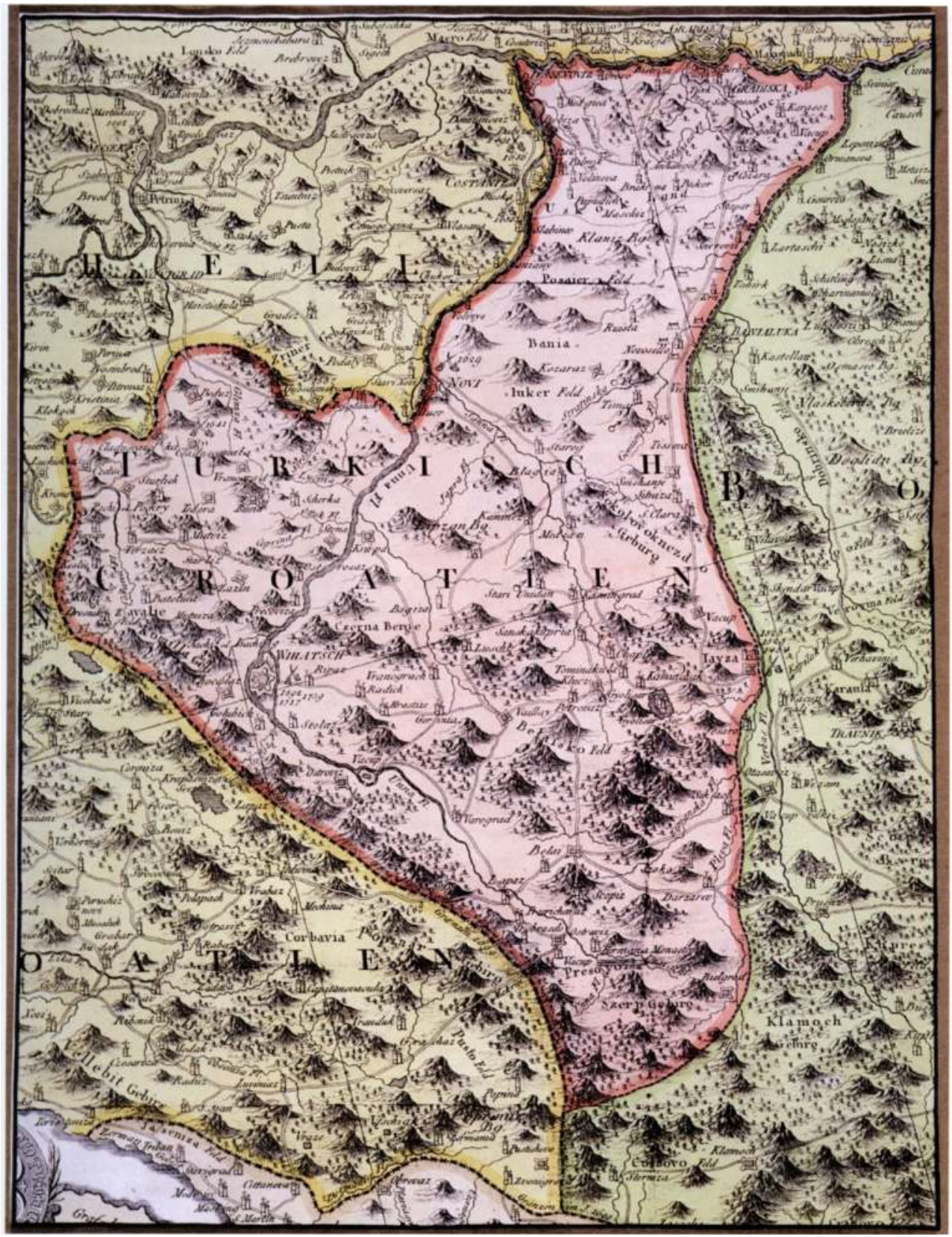

Figure 6. Schimek's map of Turkish Croatia, 1788, facsimile in [20] 
the name into Bosanska Krajina ${ }^{1}$. While the old name of Turkish Croatia emphasized the Croatian territoriality of different religious and cultural identity, the name of Bosanska Krajina is emphasizing the border character of the territory. Turkish Croatia / Bosanska Krajina retained its borderland character even later through the participation in the organization of Military Border that additionally sustained the image of otherness in terms of a particular military mentality, apart from multiculturalism. Still, Bosanska Krajina, as a regional concept, has preserved territorial coverage with an image of otherness and uniqueness in the multicultural and multiethnic sense. There has been a change in spatial image that conditioned the change, but also the preservation of regional identity and concept.

Morlacchia, on the other hand, has gone throughout its dissolution. The change of the multiethnic and multicultural triple border circumstances by the $19^{\text {th }}$ century as a consequence of the end of the wars with Ottoman Empire and the fall of Venetian Republic, has led to the dissolution of context of political significance in warfare conditions, within which the Morlacchi communities have been evaluated throughout the centuries. Additionally, administrative measures brought by Habsburg government (the destruction of goat herding with the aim of forestation, confiscation of weapons, which exposed Morlacchi districts to devastation by wolves) and disorientation in peaceful conditions led to impoverishment and transformation of Morlacchi community [27]. Morlacchi descendants in the hinterland of Dalmatian cities, either Orthodox or Catholic faith, have gradually been merged with Croats and the Serbs, mostly by religious affiliation. The change in the multicultural architecture of the space and community as well as disappearance of triple border have led to the change of the spatial image and in this particular case conditioned the disappearance of the regional identity and concept.

All these examples of socio-cultural images and spatial and regional concepts are common to all relevant European cartographies, regardless of different (and often opposed) political affiliations, interests and attitudes towards the borderlands. They are not imposed from above, from the centers of political power, but reflect an internal and local knowledge and perceptions.

\section{Conclusion}

The paper discusses the role of cartography in imaging the past, particularly taking into consideration the multiculturalism of borderlands. The starting points are two concepts, image and map i. e. the understanding of map as a socially constructed image with a number of semantic layers which reflect power relationships, distinction of social groups and system of beliefs, worldviews and what may be called a spirit of time. Borderlands are typical spaces where a multiplicity of contacts reflect and produce a multiplicity of perceptions and images.

\footnotetext{
${ }^{1}$ Krajina has a meaning of borderlands.
} 
Map deconstruction was employed as a basic research strategy in Harleian terms, signifying a search for alternative meaning, metaphor and rhetoric in the textuality of the map. Key elements of analysis were place-names and smaller cartographic transcriptions and objections as they are as much related to an invisible social world and to ideology as they are to the material world that can be seen and measured.

The selection of early modern maps of different European cartographic traditions has revealed two levels of meaning within the symbolic layer. The first one reflects different and opposed images of different cartographic traditions. These images are politically informed and valued giving legitimacy, importance and power to one side and ignoring and silencing the other, i.e. disseminating the political message of power and control and communicating the political program.

Contrasted to images that reflect different attitudes of different imperial forces and that can be easily recognized through corresponding official cartographic traditions, there is another level of meaning that reveals common socio-cultural images to all European cartographies, regardless of political affiliation. These images reflect social recognition and territorialization through the distinction of social "otherness" and, on the other hand, perceptions of territorial continuity in circumstances of border fluctuation, through the distinction of territorial "otherness".

The consciousness of the otherness and uniqueness as related to territoriality is leading to the creation of regional identity. These elements are formative elements of regional identity and the regional concept in examples discussed: in Morlacchia as well as in Turkish Croatia. These regional concepts, however, have undergone throughout different developments and have different reflections in present time. Morlacchia, as a regional concept, has dissoluted with the change of the multiethnic and multicultural triple border circumstances and the change in spatial image by the $19^{\text {th }}$ century. On the contrary, Turkish Croatia, as a regional concept, has preserved territorial coverage with an image of multiculturalism till present time, but with the stronger accentuation of its borderlands character under the new name of Bosanska Krajina. The preservation of regional concept of Turkish Croatia / Bosanska Krajina is considerably due to the longer persistence of borderlands development even later through the Military Border and linking military and multicultural components of regional identity.

All examples clearly show the external and internal power of map that is not necessarily separated. One particular map can express both - the external power which is imposed from above, especially when cartography became nationalized, but also the internal power, exercised by cartographers themselves, reflecting internal and local knowledge and perceptions.

\section{Author Details}

Borna Fuerst-Bjeliš

University of Zagreb, Faculty of Science, Department of Geography, Zagreb, Croatia 


\section{References}

[1] Mitchell W (1986) Iconology, image, text, ideology. Chicago: University of Chicago Press. $236 \mathrm{p}$.

[2] Phillips R (1993) The language of images in geography. Progress in Human Geography 17, 2: 180-194.

[3] Cosgrove D. E (1998) Social Formation and Symbolic Landscape. Madison, London: The University of Wisconsin Press. 293 p.

[4] Crampton J.W (1996) Bordering on Bosnia. GeoJournal 39: 353-361.

[5] Crampton J.W (2001) Maps as social constructions: power, communication and visualization. Progress in Human Geography 25, 2: 235-252.

[6] Panofsky E (1983) Meaning in the Visual Arts. Chicago: University of Chicago Press. $364 \mathrm{p}$.

[7] Wright J (1942) Map makers are human: comments on the subjective in maps. The Geographical Review 32: 527-544.

[8] Harley J. B (2001)The New Nature of the Maps, Essays in the History of Cartography. Laxton P editor. Baltimore: The Johns Hopkins University Press. 333 p.

[9] Harley J. B (1989) Deconstructing the Map. Cartographica 26, 2: 1-20.

[10] Black J (2000) Maps and History, Constructing Images of the Past. New Haven, London: Yale University Press. 267 p.

[11] Fuerst-Bjeliš B, Zupanc I (2007) Images of the Croatian Borderlands: Selected Examples of Early Modern Cartography. Hrvatski Geografski Glasnik 69, 1: 5-21.

[12] Fuerst-Bjeliš B (2000) Cartographic Perceptions of the Triplex Confinium and State Power Interests at the beginning of the 18th Century. In Roksandić D, Štefanec N, editors. Constructing Border Societies on the Triplex Confinium. Budapest. pp.215-220.

[13] Mlinarić D (2002) Različite percepcije ranonovovjekovnog prostora hrvatskih zemalja u domaćih i stranih kartografa. In Mežnarić S, editor. Etničnost i stabilnost Europe u 21. stoljeću. Zagreb: IMIN - Naklada Jesenski i Turk - Hrvatsko sociološko društvo. pp. 131142.

[14] Fuerst-Bjeliš B (1999-2000) Toponimija i percepcija u prostoru Triplex Confiniuma: Morlakija. Radovi 32-33: 349-354.

[15] Faričić J (2007) Geographical Names on 16th and 17th Century Maps of Croatia. Cartography and Geoinformation 6, special issue: 148-179.

[16] Fuerst-Bjeliš B (2011) Slike i mijene regionalnoga identiteta - geografska imena na kartama ranoga novoga vijeka; odabrani primjeri. In Skračić V, Faričić J, editors. Zbornik radova s Prvoga nacionalnog znanstvenog savjetovanja o geografskim imenima. Zadar: 67-72.

[17] Slukan-Altić M (2005) Kartografski izvori između povijesti i politike ili kako lagati kartama. In Lipovčan S, Dobrovšak L, editors. Hrvatska historiografija XX. stoljeća: između znanstvenih paradigmi i ideoloških zahtjeva. Zagreb: Institut društvenih znanosti Ivo Pilar. pp. 313-334.

[18] Mlinarić D (2011) Kartografska vizualizacija i slika Drugog na primjeru višestruko graničnih prostora. Migracijske i etničke teme 27, 3: 345-373. 
[19] Marković M (1993) Descriptio Croatiae. Zagreb: Naprijed. 372 p.

[20] Marković M (1998) Descriptio Bosnae et Hercegovinae. Zagreb: AGM. 496 p.

[21] Kozličić M (1995) Kartografski spomenici Hrvatskog Jadrana. Zagreb: AGM. 391p.

[22] Regan K, editor. (2003) Hrvatski povijesni atlas. Zagreb: Hrvatski leksikografski zavod "Miroslav Krleža". 386 p.

[23] Monmonier M (1996) How to Lie With Maps. Chicago, London: The University of Chicago Press. 207 p.

[24] Pandžić A (1988) Pet stoljeća zemljopisnih karata Hrvatske, Izložba Povijesnog muzeja Hrvatske. Zagreb: Povijesni muzej Hrvatske. 145 p.

[25] Marković M (1987) Prilog poznavanju djela objavljenih u zagrebačkoj tiskari Pavla Rittera Vitezovića. Starine 60: 71-79.

[26] Perković Z (1995) Croatia Rediviva Pavla Rittera Vitezovića. Senjski zbornik 22: 225-236.

[27] Modrich G (1892) La Dalmatia romana-veneta-moderna. Note e ricordi di viaggio. Torino. $506 \mathrm{p}$. 